\title{
Pure Endoscopic Excision of Parenchymal Brain Tumors: Feasibilty, Risks, Advantages and Realities - A Beginners Perspective
}

\author{
Manish Budhiraja ${ }^{1}$ Ashis Pathak ${ }^{1}$ Harmandeep Brar ${ }^{1}$ Rahat Brar ${ }^{2}$ \\ ${ }^{1}$ Department of Neurosurgery, Fortis Hospital, Mohali, India \\ 2 Department of Radiodiagnosis, Fortis Hospital, Mohali, India \\ Address for correspondence Ashis Pathak, MS, MCh., MNAMS, FICS,, \\ Department of Neurosurgery, Fortis Hospital, Mohali, India \\ (e-mail: ashispathak2006@rediffmail.com). \\ Arq Bras Neurocir 2020;39(3):201-206.
}

\begin{abstract}
Keywords

- clarity

- illumination

- learning curve

- magnification

- neuroendoscopy

Background Neuroendoscopy is gaining popularity and is reaching new realms. Young neurosurgeons are exploring the various possibilities associated with the use of neuroendoscopy. Neuroendoscopy in excision of parenchymal brain tumors is less explored, and young neurosurgeons should be aware of the realities. The present article is an approach to put forward the difficulties faced by a young neurosurgeon and the lessons learnt.

Objective To report the experience of surgical excision of parenchymal brain tumors, in selected cases, using pure endoscopic approach and to discuss its feasibility, technical benefits, risks and comparison with conventional microscopic excision.

Method Eight patients of variable age group with parenchymal brain tumors were operated upon by a single surgeon and followed up for a period varying from 6 months to 2 years. Data regarding operating time, illumination, clarity of the field, size of craniotomy, blood loss and course of recovery was evaluated. All of the tumors were resected using rigid high definition zero and $30^{\circ}$ endoscope.

Results Out of eight cases, seven had lesions in the supratentorial and one in the infratentorial location. The age group ranged from 27 to 74 years old. Near to gross total resection was achieved in all except two cases. All of the patients recovered well without any significant morbidity or mortality. Hospital stay was reduced by 1 day on average.

Conclusion Excision of parenchymal brain tumors via pure endoscopic method is a safe and efficient procedure. Although there is an initial period of learning curve, it is not steep for those already practicing neuroendoscopy, but the approach has its advantages.
\end{abstract}

\section{Introduction}

Neuroendoscopic excision of intraventricular and sellar tumors is a well-established neurosurgical technique, but the use of this approach for parenchymal tumors has not gained popularity. Several surgeons have tried combined open and endoscopic approaches with success. ${ }^{1-4}$ However, pure endoscopic resection of parenchymal brain tumors is

received

November 30, 2019

accepted

December 23, 2019 
tumor excision is a safer alternative as it allows easy entry to the tumor through the parafascicular corridor of white matter, offers better clarity of image because of the proximity of the endoscope to the brain and tumor surface. ${ }^{5}$ Also, the smaller size of craniotomy and the narrow corridor of entry is sufficient to allow bimanual manipulation of the tumor with clear visibility of the hidden corners. The technique therefore is minimally invasive and strictly adheres to proven microsurgical principles. ${ }^{6-8}$ Eight patients with parenchymal brain tumors were operated upon using the pure endoscopic method. Comparison on various parameters was done with the purely microscopic approach. The feasibility of this approach along with associated risk, benefits and misconceptions are discussed.

\section{Summary}

A total of 8 patients ( - Table 1 ), with age ranging from 27 to 74 years old, with a follow-up period of 2 months to 2 years are presented. These include three females and five male patients, out of which seven had supratentorial and one had infratentorial location of the lesions. We were able to achieve near to gross total resection in all the lesions except in two, as one lesion had close proximity to the vessels and there was misleading frozen section report in the other. Three lesions were low grade, four were high grade and one was a hemangioblastoma. Only one patient had significant deficit in the postoperative period in the form of opposite side weakness with aphasia, which recovered with time. None of the remaining patients developed any remarkable postoperative deficits.

\section{Operative Technique}

All of the patients underwent contrast-enhanced MRI under neuronavigation protocol. Following standard neuroanaesthetic technique for induction, the heads of the patients were positioned and fixed with the help of a Sugita head frame (Head support of OT table company name, Mizuho, Made in Japan, Made in Japan). Using stealth navigation system, the position of the tumor was confirmed and a limited craniotomy was planned centering on the main bulk of the lesion. Although the initial two cases had a slightly larger craniotomy as a precautionary learning curve measure, the subsequent exposures were reduced to almost half the size of standard exposures. Dural openings were similar to cruciate exposure. The site of cortisectomy was decided based on neuronavigation guidance depending upon the shortest route of entry and eloquence of structure(s) in the vicinity. Cortisectomies were tailored to the optimal space requirement for the introduction of the endoscope and maneuverability of the operating instruments. The initial debulking was performed using a zero degree scope mounted on an endoscope holder which allowed the freedom for bimanual excision. Subsequently, a $30^{\circ}$ scope was introduced for visualization of the surrounding lesion in blind corners of the cavity using minimal retraction. There was no need for the use of other angled scopes. Tumor excision followed the same principles of cautery and suction (CUSA) evacuation using navigation guidance. In the initial 2 cases, the microscope was brought in at the end of surgery to confirm the definition of the tumor-brain interface, which reaffirmed good tumor clearance. In initial cortisectomies, the margins were not supported leading to subpial hemorrhages and cortical changes. Subsequent use of gloves strips circumvented the issue. Hemostasis was achieved in the usual manner followed by complete dural closure in every case.

\section{Results}

A total of eight patients of intraparenchymal lesions were operated in the present series, out of which seven were supratentorial and one was in infratentorial location. The age group ranged between 27 and 74 years old. Near to gross total resection was achievable in all of the cases, except in two (-Fig. 1,2 and 3). One patient with a dominant frontotemporal lobe tumor developed hemiparesis and motor aphasia in the postoperative period, which recovered gradually. The remaining patients had no neurological deficit ( - Table 2). Considering

Table 1 Details of the patients including types of tumors and postoperative complications

\begin{tabular}{|c|c|c|c|c|c|}
\hline Case No & Age/Sex & Location & Resection & Histopathology & Complication \\
\hline 1. & $27 \mathrm{yrs} / \mathrm{F}$ & $\begin{array}{l}\text { Left temporal } \\
\text { (-Fig. 1) }\end{array}$ & Near total & $\begin{array}{l}\text { Diffuse infiltrating } \\
\text { astrocytoma Grade II }\end{array}$ & Nil \\
\hline 2. & $34 \mathrm{yrs} / \mathrm{F}$ & $\begin{array}{l}\text { Left posterior frontal } \\
\text { (-Fig. } 2 \text { ) }\end{array}$ & Gross total & Oligodendroglioma Grade II & $\begin{array}{l}\text { Right hemiparesis } \\
\text { with aphasia }\end{array}$ \\
\hline 3. & $57 \mathrm{yrs} / \mathrm{M}$ & Left cerebellar & Gross total & Hemangioblastoma Grade I & Nil \\
\hline 4. & $74 \mathrm{yrs} / \mathrm{M}$ & $\begin{array}{l}\text { Right parieto occipital } \\
\text { (-Fig. } \mathbf{3} \text { ) }\end{array}$ & Gross total & $\begin{array}{l}\text { Glioblastoma multiforme } \\
\text { Grade IV }\end{array}$ & Nil \\
\hline 5. & $36 \mathrm{yrs} / \mathrm{F}$ & Left perisylvian & Gross total & Astrocytoma grade III & Nil \\
\hline 6. & $64 \mathrm{yrs} / \mathrm{M}$ & Right parieto occipital & Subtotal & $\begin{array}{l}\text { Glioblastoma Multiforme } \\
\text { Grade IV }\end{array}$ & Nil \\
\hline 7. & $33 \mathrm{yrs} / \mathrm{M}$ & Right Frontal & Near total & Oligodendroglioma grade II & $\mathrm{Nil}$ \\
\hline 8. & $59 \mathrm{yrs} / \mathrm{M}$ & Left Fronto-Parietal & Gross total & $\begin{array}{l}\text { Glioblastoma Multiforme } \\
\text { Grade IV }\end{array}$ & Nil \\
\hline
\end{tabular}

Abbreviations: F, female; M, male. 


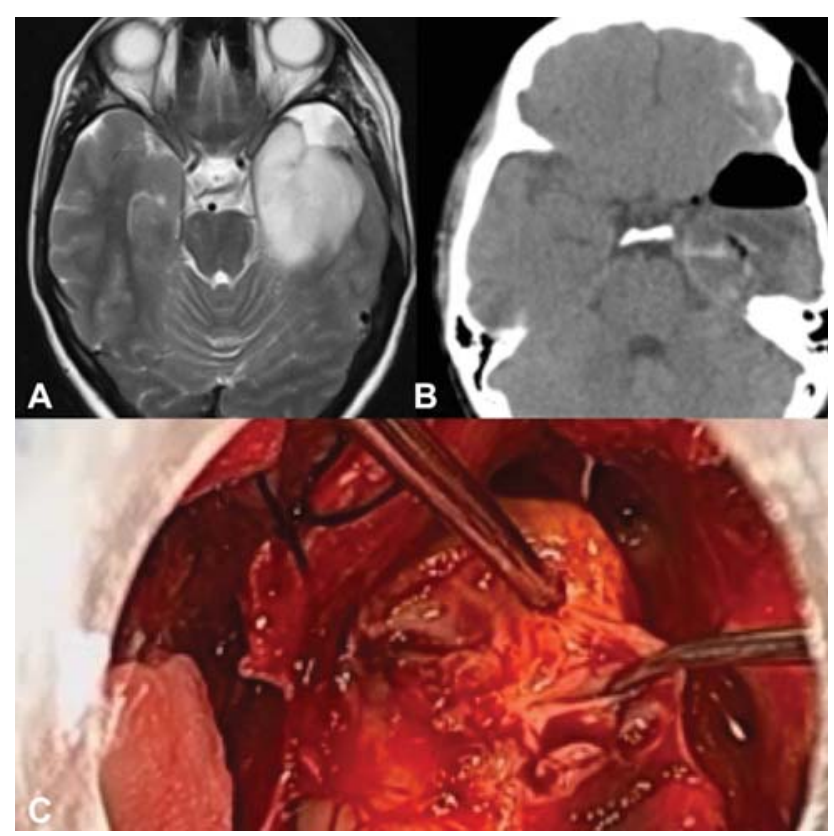

Fig. 1 (A) Axial T2 weighted magnetic resonance imaging showing the heterogenous hyperintense lesion in the anterior temporal lobe showing ill-defined margins. (B) Axial computed tomography image showing postoperative changes in the left temporal lobe and foci of air in the operative bed. (C) Intra operative endoscopic view during tumor excision showing partly fibrous tumor.

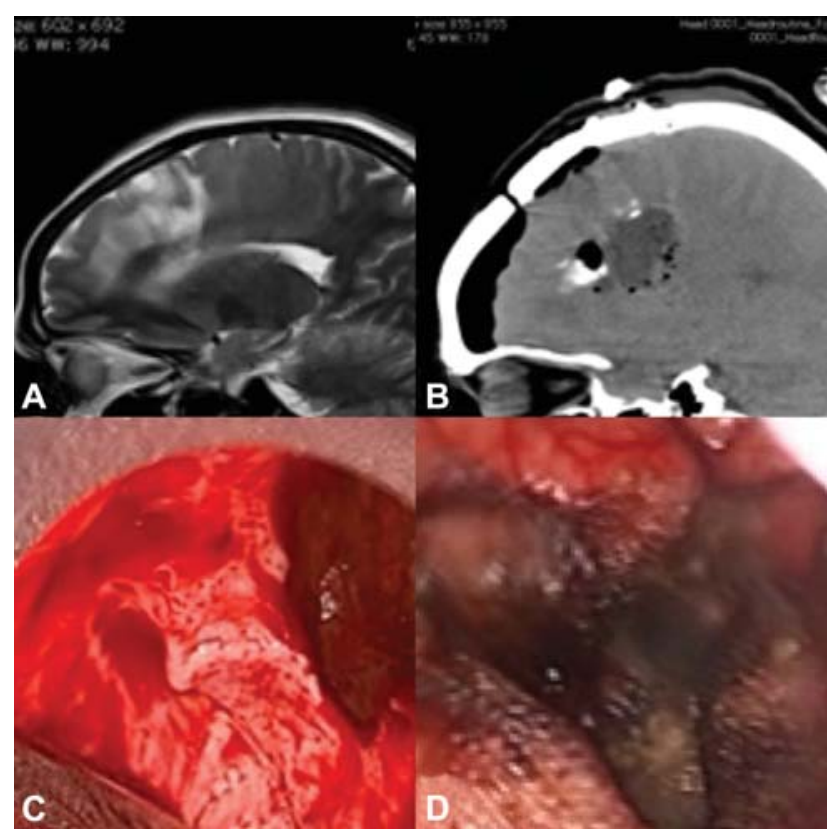

Fig. 2 (A) T2 weighted sagittal image of the brain showing lesion in the left frontal lobe. (B) Sagittal computed tomography image showing postoperative changes in the left frontal lobe with small foci of air at the postoperative site and extra axial nondependent air in the frontal region. (C) Intraoperative endoscopic image showing tumor tissue. (D) Endoscopic view after tumor excision showing the surgicel lining at the margins.

the evaluation of the endoscopic technique with microscopic procedure, the parameters compared were: operating time, illumination, clarity, magnification, blood loss, size of craniotomy, postoperative imaging. The surgical time was slightly

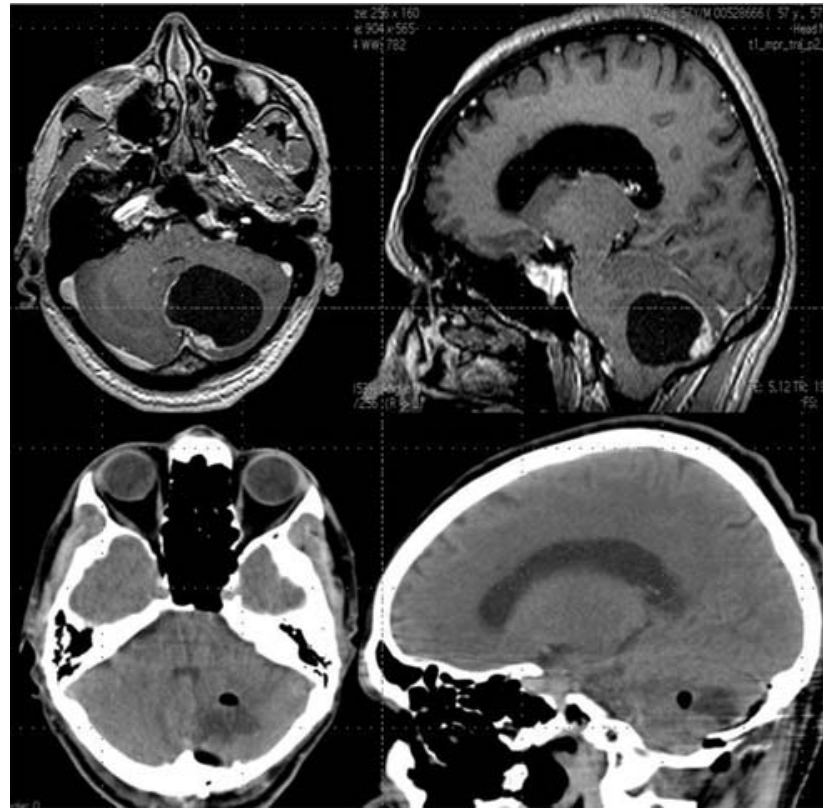

Fig. 3 (A and B) Preoperative axial and sagittal T1 contrast magnetic resonance imaging showing large cystic tumor with enhancing nodule in the left cerebellum. (C and D) Postoperative axial and sagittal plain computed tomography images showing complete excision with no tumor bed hematoma.

longer than the microsurgical technique, most likely due to our learning curve, but blood loss was comparable to that of the microscopic technique. The illumination, clarity and magnification were at par with the microscope, but the blind corners were much better visualized with good clarity (-Table 2; -Fig. 1, 2). We saw a significant reduction in craniotomy size (-Fig. 3). The extent of excision was $>95 \%$ in all cases except one; although the number of patients was not adequate to reach any conclusion, adequate visualization of blind corners definitely helped in excising the tumors with a good limit of confidence and safety with minimal damage to the normal tissue due to small cortisectomies. The patients recovered well and were discharged home on average 1 day earlier than those who were submitted to the routine microscopic approach with large craniotomy (-Table 2 and $\mathbf{3}$ ). A concise comparison between the standard microscopic approach and the pure endoscopic approach, with emphasis on selected important points, is shown in - Table 4.

\section{Discussion}

Pure endoscopic resection of intraparenchymal brain tumors is a minimally invasive approach that is not routinely practiced by neurosurgeons. To the best of our knowledge, until now, there are two major series with 21 and 48 cases, respectively, by Kasam et $\mathrm{al}^{1}$ and Plaha et $\mathrm{al}^{2}$ with few other sporadic reports ( $\mathbf{-}$ Table $\mathbf{5}$ ). The reason for the lower popularity of this technique is due to the unfamiliarity with the procedure, the long learning curve and apprehension about inadequate exposure and inadequate visibility through the endoscope. 
204 Pure Endoscopic Parenchymal Brain Tumor Excision Pathak et al.

Table 2 Evaluation of Parameters in pure endoscopic method

\begin{tabular}{|c|c|c|c|c|c|c|c|c|c|}
\hline S No & Parameters & $\begin{array}{l}\text { Case I } \\
\text { (-Fig. 1) }\end{array}$ & $\begin{array}{l}\text { Case II } \\
\text { (-Fig. 2) }\end{array}$ & Case III & $\begin{array}{l}\text { Case IV } \\
\text { (-Fig. 3) }\end{array}$ & Case V & Case VI & Case VII & Case VIII \\
\hline 1 & Surgical Time & $\begin{array}{l}2 \text { hrs } 15 \\
\text { mins }\end{array}$ & $\begin{array}{l}3 \text { hrs } 25 \\
\text { mins }\end{array}$ & $2 \mathrm{hr} 45$ mins & $2 \mathrm{hr} 50$ mins & 2 hrs 30 mins & 2 hrs 10 mins & $1 \mathrm{hr} 50$ mins & $\begin{array}{l}2 \text { hrs } 10 \\
\text { mins }\end{array}$ \\
\hline 2 & $\begin{array}{l}\text { Illumination \& } \\
\text { Clarity }\end{array}$ & $\begin{array}{l}\text { Very good } \\
\text { specially at } \\
\text { corners }\end{array}$ & $\begin{array}{l}\text { Very good } \\
\text { specially at } \\
\text { corners }\end{array}$ & $\begin{array}{l}\text { Very good } \\
\text { specially at } \\
\text { corners }\end{array}$ & $\begin{array}{l}\text { Very good } \\
\text { specially at } \\
\text { corners }\end{array}$ & $\begin{array}{l}\text { Very good } \\
\text { specially at } \\
\text { corners }\end{array}$ & $\begin{array}{l}\text { Very good } \\
\text { specially at } \\
\text { corners }\end{array}$ & $\begin{array}{l}\text { Very good } \\
\text { specially at } \\
\text { corners }\end{array}$ & $\begin{array}{l}\text { Very good } \\
\text { specially at } \\
\text { corners }\end{array}$ \\
\hline 3 & Magnification & $\begin{array}{l}\text { Tumor brain } \\
\text { interface } \\
\text { well differ- } \\
\text { entiated }\end{array}$ & $\begin{array}{l}\text { Tumor brain } \\
\text { interface } \\
\text { well differ- } \\
\text { entiated }\end{array}$ & $\begin{array}{l}\text { Tumor brain } \\
\text { interface } \\
\text { well differ- } \\
\text { entiated }\end{array}$ & $\begin{array}{l}\text { At par with mi- } \\
\text { croscope with } \\
\text { little difficulty in } \\
\text { hemostasis at } \\
\text { depth }\end{array}$ & $\begin{array}{l}\text { At par with } \\
\text { microscope } \\
\text { with little } \\
\text { difficulty in } \\
\text { hemostasis at } \\
\text { depth }\end{array}$ & $\begin{array}{l}\text { Tumor brain } \\
\text { interface well } \\
\text { differentiated }\end{array}$ & $\begin{array}{l}\text { At par with } \\
\text { microscope } \\
\text { with little } \\
\text { difficulty in } \\
\text { hemostasis } \\
\text { at depth }\end{array}$ & $\begin{array}{l}\text { Tumor brain } \\
\text { interface } \\
\text { well differ- } \\
\text { entiated }\end{array}$ \\
\hline 4 & Blood Loss & $150-200 \mathrm{ml}$ & $200 \mathrm{ml}$ & $200 \mathrm{ml}$ & $250-300 \mathrm{ml}$ & $400 \mathrm{ml}$ & $150-200 \mathrm{ml}$ & $100-150 \mathrm{ml}$ & $150-180 \mathrm{ml}$ \\
\hline 5 & $\begin{array}{l}\text { Craniotomy } \\
\text { Size }\end{array}$ & $\begin{array}{l}70 \% \text { of } \\
\text { microscopic }\end{array}$ & Standard & $\begin{array}{l}50 \% \text { of } \\
\text { microscopic }\end{array}$ & $\begin{array}{l}40 \% \text { of } \\
\text { microscopic }\end{array}$ & $\begin{array}{l}60-70 \% \text { of } \\
\text { microscopic }\end{array}$ & $\begin{array}{l}\text { Standard } \\
\text { (extensive } \\
\text { edema) }\end{array}$ & $\begin{array}{l}60 \% \text { of mi- } \\
\text { croscopic }\end{array}$ & $\begin{array}{l}60-70 \% \text { of } \\
\text { microscopic }\end{array}$ \\
\hline 6 & $\begin{array}{l}\text { Tumor bed } \\
\text { hematoma }\end{array}$ & No & Small & No & $\begin{array}{l}\text { Significant but } \\
\text { without mass } \\
\text { effect }\end{array}$ & $\begin{array}{l}\text { Significant but } \\
\text { no mass effect }\end{array}$ & Small & Nil & Small \\
\hline
\end{tabular}

Table 3 Evaluation of parameters in randomly selected cases of pure microscopic excision of parenchymal tumors

\begin{tabular}{|c|c|c|c|c|c|c|c|c|c|}
\hline S No & Parameters & Case I & Case II & Case III & Case IV & Case V & Case VI & Case VII & Case VIII \\
\hline 1 & Surgical Time & 1 hrs 50 mins & $\begin{array}{l}1 \text { hrs } 45 \\
\text { mins }\end{array}$ & $2 \mathrm{hr} 30 \mathrm{mins}$ & $2 \mathrm{hr} 15$ mins & $2 \mathrm{hrs}$ & 2 hrs 10 mins & $1 \mathrm{hr} 50$ mins & $\begin{array}{l}2 \text { hrs } 25 \\
\text { mins }\end{array}$ \\
\hline 2 & $\begin{array}{l}\text { Illumination \& } \\
\text { Clarity }\end{array}$ & $\begin{array}{l}\text { Poor at } \\
\text { corners no } \\
\text { visualization } \\
\text { of undermining } \\
\text { edges }\end{array}$ & $\begin{array}{l}\text { Poor at } \\
\text { corners no } \\
\text { visualization } \\
\text { of under- } \\
\text { mining } \\
\text { edges }\end{array}$ & $\begin{array}{l}\text { Poor at } \\
\text { corners no } \\
\text { visualization } \\
\text { of under- } \\
\text { mining } \\
\text { edges }\end{array}$ & $\begin{array}{l}\text { Poor at } \\
\text { corners no } \\
\text { visualization } \\
\text { of under- } \\
\text { mining } \\
\text { edges }\end{array}$ & $\begin{array}{l}\text { Poor at } \\
\text { corners no } \\
\text { visualization } \\
\text { of undermin- } \\
\text { ing edges }\end{array}$ & $\begin{array}{l}\text { Poor at } \\
\text { corners no } \\
\text { visualization } \\
\text { of undermin- } \\
\text { ing edges }\end{array}$ & $\begin{array}{l}\text { Poor at } \\
\text { corners no } \\
\text { visualization } \\
\text { of undermin- } \\
\text { ing edges }\end{array}$ & $\begin{array}{l}\text { Poor at } \\
\text { corners no } \\
\text { visualization } \\
\text { of under- } \\
\text { mining } \\
\text { edges }\end{array}$ \\
\hline 3 & Magnification & Good & Good & Good & Good & Good & Good & Good & Good \\
\hline 4 & Blood Loss & $100-120 \mathrm{ml}$ & $100-120 \mathrm{ml}$ & $100-150 \mathrm{ml}$ & $300 \mathrm{ml}$ & $100 \mathrm{ml}$ & $150-200 \mathrm{ml}$ & $100-120 \mathrm{ml}$ & $150 \mathrm{ml}$ \\
\hline 5 & $\begin{array}{l}\text { Craniotomy } \\
\text { Size }\end{array}$ & Large & $\begin{array}{l}\text { Decom } \\
\text { pressive }\end{array}$ & $\begin{array}{l}\text { Standard } \\
\text { according to } \\
\text { tumor size }\end{array}$ & $\begin{array}{l}\text { Standard } \\
\text { according to } \\
\text { tumor size }\end{array}$ & $\begin{array}{l}\text { Standard } \\
\text { according to } \\
\text { tumor size }\end{array}$ & $\begin{array}{l}\text { Standard } \\
\text { according to } \\
\text { tumor size }\end{array}$ & $\begin{array}{l}\text { Standard } \\
\text { according to } \\
\text { tumor size }\end{array}$ & $\begin{array}{l}\text { Standard } \\
\text { according to } \\
\text { tumor size }\end{array}$ \\
\hline 6 & $\begin{array}{l}\text { Tumor bed } \\
\text { hematoma }\end{array}$ & No & No & Small & No & Small & No & No & No \\
\hline
\end{tabular}

Table 4 Comparison of pure endoscopic with pure microscopic excision in parenchymal brain tumors

\begin{tabular}{|l|l|l|l|}
\hline S No & Parameters & Pure Microscopic & Pure Endoscopic \\
\hline 1. & Surgical Time & Less time consuming & Comparatively more due to learning curve initially \\
\hline 2. & Illumination and clarity & Poor at Blind Corners & Neatly visualized and especially undermined edges \\
\hline 3. & Magnification & Good with 3D vision & At par with microscope but with comparatively difficult depth perception \\
\hline 4. & Blood Loss & Better controlled & $\begin{array}{l}\text { Sometimes difficult to control due to difficult depth perception } \\
\text { Microscope can aid at the end of surgery in case of difficulty }\end{array}$ \\
\hline 5. & Craniotomy Size & Large craniotomy & Mini craniotomy size reduction by minimum of 20-30\% \\
\hline 6. & Tumor bed hematoma & Lower incidence & Incidence may be higher due to learning curve initially. \\
\hline
\end{tabular}

Table 5 Summary of major studies of pure endoscopic approach for excision of parenchymal brain tumors

\begin{tabular}{|c|c|c|c|c|}
\hline Author & Method & Type of endoscope & Extent of resection & Limitations \\
\hline $\begin{array}{l}\text { Kassam et } \\
\text { al, } 2009^{1}\end{array}$ & $\begin{array}{l}\text { Neuroendoport } \\
\text { Conduit } 11.5 \mathrm{~mm}\end{array}$ & $\begin{array}{l}\text { 0-degree } \\
\text { endoscope }\end{array}$ & $\begin{array}{l}\text { Total resection } 38 \% \text {, near total } 28.6 \% \text {, sub- } \\
\text { total } 33.3 \% \text { multiple }\end{array}$ & $\begin{array}{l}\text { Manipulations of conduit required to achieve } \\
\text { maximal resection. Conduit cannot be used } \\
\text { for tumors reaching pial surface }\end{array}$ \\
\hline $\begin{array}{l}\text { Jo et al, } \\
2011^{4}\end{array}$ & $\begin{array}{l}\text { Transparent tubu- } \\
\text { lar conduit } 11 \mathrm{~mm}\end{array}$ & $\begin{array}{l}\text { 0-degree } \\
\text { endoscope }\end{array}$ & Gross total resection in all cases & Small lesions $(3 \mathrm{~cm})$ limited \\
\hline $\begin{array}{l}\text { Otsuki et al., } \\
1990^{3}\end{array}$ & $\begin{array}{l}\text { Tubular conduit on } \\
\text { stereotactic frame }\end{array}$ & $\begin{array}{l}\text { 0-degree } \\
\text { endoscope }\end{array}$ & $\begin{array}{l}\text { Total resection in } 8 \text { lesions; biopsy or aspira- } \\
\text { tion in } 7\end{array}$ & Small lesions limited by size of conduit \\
\hline $\begin{array}{l}\text { Plaha et al, } \\
2014^{2}\end{array}$ & $\begin{array}{l}\text { Nontubular access } \\
\text { corridor } 10 \mathrm{~mm}\end{array}$ & $\begin{array}{l}\text { 30-degree } \\
\text { endoscope }\end{array}$ & Total resection $48 \%,>95 \%$ resection $70 \%$ & $\begin{array}{l}\text { Needs further development of microsurgical } \\
\text { instruments and access corridor }\end{array}$ \\
\hline $\begin{array}{l}\text { Present } \\
\text { study }\end{array}$ & $\begin{array}{l}\text { Nontubular access } \\
\text { corridor } 10-15 \mathrm{~mm}\end{array}$ & $\begin{array}{l}0 \text { and } 30 \text {-degree } \\
\text { endoscope }\end{array}$ & Near total to gross total resection & $\begin{array}{l}\text { Limited number of patients \& variability in } \\
\text { types of lesions }\end{array}$ \\
\hline
\end{tabular}


Although it is perceived that endoscopic brain tumor resection requires a long learning curve, neurosurgeons familiar with endoscopic transphenoidal procedures would already have a hang of working in a narrow, rigid corridor within the bounds of limited space. Selected entry through cortisectomy using a safe surgical corridor under neuronavigation guidance gives an easy access to the lesions. However, the maneuvering of the endoscope and the instruments need to be more gentle because of the risk of retraction injury to the normal parenchyma around the port of entry. Although the use of rigid conduits has been claimed to be less harmful as compared with normal brain retractors, ${ }^{9}$ we agree with the proposed argument that a constant pressure on the brain would add to ischemic insults apart from compression effect on the surrounding normal parenchyma. ${ }^{2,10}$ According to our experience, the use of a pulsatile retractor combined with latex glove lining provides the advantage of minimizing traction effect and allowing the desired exposure needed for resection. As a beginner, it is suggested to perform the initial cases with slightly larger exposure so as to have a leeway to revert to microscopic excision if the surgeon is inconvenienced at any stage.

Comparing the illumination and visibility between microscopic versus endoscopic excision, undoubtedly the microscope gives better resolution. However, it is also true that for deeper entry corridors there is considerable loss of light leading to poor visibility and resolution in microscopic techniques in deeper areas. This problem is compounded by manipulation of instruments at the depth. Contrarily, the endoscope has the advantage of better optical resolution as the light source is nearer to the target. This enhances the visibility and adds advantage to better differentiation of the brain-tumor interface without compromising the magnification of the image.

Resection of a lesion without fresh neurological deficit remains a major challenge in all intraparenchymal lesions. The microscopic vision is limited by straight projection of light rays at the depth of the surgical field, which is different from endoscopic visualization as it provides a wide-angled panoramic view, giving better clarity at the depth. Moreover, the use of an angled endoscope can help in viewing the blind corners without much manipulation or retraction.

\section{Our Learning Experience}

Usually a single surgeon will suffice in the microscopic approach, but in the endoscopic approach there may be the need of an assistant to hold the scope and navigate. In the present series, the need for two persons was obviated by mounting the endoscope on a holder which gave an unhindered opportunity for bimanual excision by a single surgeon. However, it may take a while to switch over and get oriented from the resolution of a microscope to endoscope. As a beginner, it is always safe to begin with a bigger exposure and have a fall back option to bring in the microscope, if the situation demands. As it happened in one of our cases, it was decided to use the microscope for a brief period since there was difficulty in manipulating between the vessels of the sylvian fissure in a peri-sylvian lesion (case no $5,-$ Table $\mathbf{1}$ ).
Hence, there should not be any dogma to use technology interchangeably in situations on demand.

Cortisectomy length of 1.5 to $2 \mathrm{~cm}$, which was initially supported by cotton patties, led to widening of the cortisectomy margins and damage to the edges. Subsequently, it was planned to insulate the edges with surgicel superimposed with glove patties with overlying cotton patties to hold them in place. Using this technique, the damage to the surrounding brain and to the extension of the cortisectomy margins was reduced to minimum, thus achieving near total resection in most of the cases avoiding unwanted cortical injury.

The resection of a lesion is facilitated by the initial use of a zero degree scope. Subsequent to reasonable debulking/ excision of the tumor, the use of a $30^{\circ}$ scope with minimal sector wise retraction of the corticectomy margins helps in achieving a total excision of the lesion, even at blind corners, through good resolution and visibility. The use of more obtuse angled scopes, in our experience, is not necessary.

\section{Outcome and Complications}

The level of resection achieved in previous studies varies from $29 \%$ to $>95 \% .{ }^{1-4}$ We achieved near to gross total resection in all cases and the illumination, magnification and clarity was excellent. However, this is a small series to comment upon the exact extent of the excision of the lesions in a wide variety of cases. The blood loss in all cases was comparable to that of microscopic excision, with no postoperative tumor bed hematoma in any case. One patient with oligodendroglioma (case no 2, - Table 1) situated in a strategic location in the dominant hemisphere, developed aphasia and right side weakness which improved gradually over a period of time. Although there was the issue of depth perception initially, that was overcome with subsequent experience. It is most important that the surgeon conducts a critical evaluation of clinical and radiological findings before embarking upon endoscopic excision, and also weighs the plausibility of conversion to microscopic excision to avoid any adventurous complications. The issue of falling brain and managing brisk bleeding in a vascular tumor bed may at times blind the vision through a scope. Hence a steady and slow resection of vascular lesions in a controlled way is likely to achieve the goal of satisfactory resection. As mentioned earlier, there should not be any hesitation to resort to the help of a microscope in situations of brisk bleeding. The resection of surface tumors, in our experience, turned out to be an easier option with hardly any need for retraction. This technique was demonstrated to be accurate and safe, and possibly will be expanded to remove other intraparenchymal lesions in the future. ${ }^{11}$

\section{Conclusion}

In spite of its innovative and beneficial aspects, neuroendoscopy, like any other diagnostic and treatment technique, has some risks. The most significant is perhaps the risk of local injury to the surrounding structures and normal brain. Other risks of neuroendoscopy include hemorrhage (with an associated difficulty in hemostasis) leading to raised intracranial 
pressure. However, this procedure has high future potentials to establish itself as a minimally invasive technique, although it still remains in its nascent phase. With ongoing development of endoscopic instruments and advanced surgical techniques including multiport approaches, endoscopic surgery will be expanded beyond intraventricular and skull base lesions to intraparenchymal brain lesions. These advances will be important for the future of endoscope-assisted microsurgery. In the future, neuroendoscopy is expected to become routine in modern neurosurgical practice. Institutions should develop training programs for young neurosurgeons. ${ }^{12}$

\section{Conflict of Interests}

The authors have no conflict of interests to declare.

\section{References}

1 Kassam AB, Engh JA, Mintz AH, Prevedello DM. Completely endoscopic resection of intraparenchymal brain tumors. J Neurosurg 2009;110(01):116-123

2 Plaha P, Livermore LJ, Voets N, Pereira E, Cudlip S. Minimally invasive endoscopic resection of intraparenchymal brain tumors. World Neurosurg 2014;82(06):1198-1208

3 Otsuki T, Jokura H, Yoshimoto T. Stereotactic guiding tube for open-system endoscopy: a new approach for the stereotactic endoscopic resection of intra-axial brain tumors. Neurosurgery 1990;27(02):326-330

4 Jo KW, Shin HJ, Nam DH, et al. Efficacy of endoport-guided endoscopic resection for deep-seated brain lesions. Neurosurg Rev 2011;34(04):457-463

5 Teo C, Mobbs R. Neuroendoscopy. In: Setti S. Rengachary, Richard G. Ellenbogen, eds. Principals of Neurosurgery. 2nd ed. London, UK: Elsevier Lifesciences; 2004: chapter 10

6 Kelly PJ, Goerss SJ, Kall BA. The stereotaxic retractor in computerassisted stereotaxic microsurgery. Technical note. J Neurosurg 1988;69(02):301-306

7 Kelly PJ, Kall BA, Goerss S, Earnest F IV. Computer-assisted stereotaxic laser resection of intra-axial brain neoplasms. J Neurosurg 1986;64(03):427-439

8 Russell SM, Kelly PJ. Volumetric stereotaxy and the supratentorial occipitosubtemporal approach in the resection of posterior hippocampus and parahippocampal gyrus lesions. Neurosurgery 2002;50(05):978-988

9 Zhong J, Dujovny M, Perlin AR, Perez-Arjona E, Park HK, Diaz FG. Brain retraction injury. Neurol Res 2003;25(08):831-838

10 Yokoh A, Sugita K, Kobayashi S. Intermittent versus continuous brain retraction. An experimental study. J Neurosurg 1983;58 (06):918-923

11 Sgouros S. Neuroendoscopy: current status and future trends. ed 1. Heidelberg: Springer Science \& Business Media; 2013

12 Shim KW, Park EK, Kim D-S, Choi J-U. Neuroendoscopy: Current and Future Perspectives. J Korean Neurosurg Soc 2017;60(03):322-326 